\title{
A Breezy Call of Envied Kiss In Thomas Gray's Country Churchyard
}

\author{
Nandeswar Deori \\ United Tribal Degree College \\ Lakhimpur, Assam, India \\ gurubor78@gmail.com
}

\begin{abstract}
A great poem that touches the core heart of the readers executing the rustic forefathers' lives and emotions is nothing but Gray's Country Churchyard which uplands the lawn with kindred spirit. Gray harnesses the poem with the breezy calls that enviously kiss us in the destiny of "homely joys". The humble buried beds are not only twittering ears of Gray but also they are the signification of clarion call that figure out solemn background of the rude forefathers who unlike the citizen of city swelled their "paths of glory" against the "inevitable hour'. As an advocate of the down-trodden, Gray tries to persuade that the rich should not look down upon the poor. The poor are also respectable being though they do not get an opportunity to elevate their lives as do the rich. Furthermore, though they were not able to cremate their dead bodies in the boundary of the churchyard, it was not their faults. Despite the wealthy and the proud people though get place to be cremated in the churchyards singing the hymns in honor of dead, they suffer huge setbacks in this worldly affairs. Because time is the grand
\end{abstract}


mower whose sickle never leaves anybody whether rich or poor but mows down all forever.

Keywords: Breezy Call; Envied Kiss; Rude Forefathers; Inevitable Hour, Country Churchyard.

Thomas Gray is one the greatest poets that ever produced in England. His Country Churchyard that propels him incessantly from era to era like the haunting waves of a sea among the readers is, in the words of Louis Cazamian, that 'this extremely attentive art guides a sincere inspiration without stifling it". Love and humanity play a vital role in this poem. Gray extends his sympathy to the rude forefathers who could deserve ordinary but pleasant life keeping themselves far away from the frantic and panic-stricken city life. Gray does not delineate the picture of an age but he lively penetrates into the certain universal human heart appealing "'sturdy stroke" that the coming age will enthusiastically flush its poetic fire. The poet sitting in a country churchyard got the inspiration to draw the rustic forefathers' day-to-day activities as did Wordsworth realized zeal and zest to relish the sweet lore of nature sitting in the lonely grove. This simple and plain but full of grand and grandiose poem illustrates the interesting country life. It is like a call of breeze that enviously kiss us in our heart and mind. Gray, like eolian harp, hums his tuning sound at the bay of the country forefathers who loved and shared their emotions with their wives and children after the field labor when they returned in the evening to their hamlets. Gray therefore exquisitely passages his lines---

" The curfew tolls the knell of parting day, 
The lowing herd wind slowly o'er the lea.

The plowman homeward plods his weary way, And leaves the world to darkness and me."

In this poem, Grey explains not only the country life but also their emotional life. His delineating images in the Country Churchyard poetically refines echoes in the major parts of the poem with the human emotions along with the philosophical views. Dr. Johnson therefore deserves that 'the Churchyard abounds with images which every bosom returns an echo." By meditating about the simple forefathers of the village, the poet thinks that the uneducated forefathers are buried outside the churchyard where the elm trees and yew trees are growing. But, nay, their mounds of graves are overlapped by the variety of grasses whereas the rich people's tombs are inside the church that erected by the concrete and the mortar. The rural farmers graves are jungle-based graves that never again did prone after the cremation of the earthly bodies but the graves of the wealthy people are ever lighten and colored. Though the poet feels dejected seeing the forefathers' waning graves, he gets satisfaction that the rich man's raising pyramids over the graves are meaningless. Gray further spread his ray that rich should keep away to look down upon the poor. He asserts that some have glorious power and sky-kissing buildings. Some may have plated eye-catching beauty with their money and wealth by which they relegated the poor. But they forget that death makes parallel to all after the departure of the soul. Death is the ultimate end of every life. Death does not know the pillar that distinguishes rich and poor. Rich man's beauty, glory, power and wealth all have mowed down by the satanic 
hands of time as Shakespeare says in his Sonnet 60 "Time doth transfix the flourish.....and delves the parallels in beauty's brow." In the beautiful words of Gray, " The boast of heraldy, the pomp of power,

And all that beauty, all that wealth e'er gave Awaits alike th' inevitable hour.

The paths of glory lead but to the grave."

Furthermore, Gray, being the harbinger of the poor, has seen that the well-to-do of his time did not have sympathy over the poor. The conditions of the downtrodden forefathers brought sad to the poet's heart. Consequently, he appeals rich and ambitious people that they should have a room in their heart's corner upon the downtrodden since they are the crop growers and food givers in the paddy field. These farmers are simple and easy-going in their domestic lives. Gray, again, sincerely calls upon the people who spend their money for pomp and show and live for luxury should have a tender heart to the lives of the village downtrodden. In this matter, R. F. Charles advocates beautifully, 'The pride of the aristocrat in his noble birth, the grandeur of the statesman, the gifts of the beauty and of wealth do not justify that their possessors in disdaining the simple, obscure, but useful lives of the poor, because Death awaits all alike, and all the paths that seem to lead to glory lead but to the grave."

Gray, being a pacifist, also turns his pen showing his sympathy towards the downtrodden. He begs the rich people not to blame the poor rustics although their descendants' have not able to get the earthly body to be cremated in the pyramidal and memorial stone. Born to be a poor is not their curse and fault. Born to a poor family is 
fate gifted. It is written by Fate. Yet, although they are not able to gain a place to be buried inside the church singing the hymns, does not signify that they are negligible. They are a part of human being. Both rich and poor are the recto and verso of a human society. Rich can be decorated in all ways in their lives but they are hugely unable to store their lives. Gray, therefore, satirises that though the rich try to live a showy and pompous life and preserve even the dead man's ashes in the costly urns according to the Roman Catholic churches in England, all are become worthless. This is unconquerable irony in their lives. Showing highly luxurious life and preserving the ashes in costly urns do not help them to preserve their lives forever. After death, rich and poor are equally 'lead but to grave.' The poet therefore raises an honest question to the rich,

'Can storied urn or animated bust

Back to its mansion call the fleeting breath?

Can honor's voice provoke the silent dust,

Or Flatt'ry soothe the dull cold ear of Death?"

Gray also tells that the rich get the coveted goal and achievement in their lives because of their money and power. After death, they too get yards of church to be cremated their mundane body with pomp and gusto. Even their ashes are preserved well in the costly and decorated urns to show their offspring. The forefathers of the village did not able to achieve the luxurious lives and they only got the farming techniques wallowing alongside the cattle and left the earthly world unknown. But it does not say that the forefathers of the village were by no means inferior to the well-to-do. Though some forefathers of the village were buried in the abject part of the churchyard, they 
might have great poetic creations and have divine inspiration. Their inspiration and hard labor might have brought great accolade and reputation as the spiritual masters. Among them, some might have ascended to the throne with their hale and strong hands and ruled a large empire with the subjects. Gray also tells some farmers might have achieved great musicians who might have generated bewitching and melodious music playing the lyre. But, alas, poverty became an unconquerable sea that had prevented their life-wave to reach the other side bank. As a result, their flowering talents began waning in the buds as the airless, waterless, and warmless seeds.

But Gray, the iconic figure, gets pacification seeing over the purest gems of the poor farmers as did Wordsworth get consoling and inspiring zeal sitting in the bosom of the nature by giving two metaphors. First he laps a symbolic comparison that the poor village folks are the brightest gems that ever lurk in the darkest and deepest bosom of the oceans. Man cannot have enjoyed the purity and beauty of the rare gems that remain hidden and garnered in the bottom of the sea because of its unfathomable depth and out of reach. Secondly, the poet says the fragrant flowers that comes into efflorescence in the solitary or desert places are wasted their fragrance due to the unseen or the dearth of praiseworthy of the blossoming flowers by the human beings. Likewise, the great qualities and the creative works of forefathers of the village could not able to identify by the outsiders as do the modern techno-savvy men conduct on the podium and could not get an opportune way for the development of their lives because they were on the extreme bank of penury. Consequently, the evocative talents of the poverty ridden villagers never came into front page and sweetening and ameliorating talents were filled by earth along with their departed soul. In the moving words of Gray, 
"Full many a gem of purest ray serene, The dark unfathom'd caves of ocean bear:

Full many a flower is born to blush unseen, And waste its sweetness on the desert air."

One of the interesting point that Gray has contrasted the city life and the country life in his Elegy as do the sociologists. Like Marx, the great poet has seen the base of the rich who determines the superstructure of the poor predominantly that influence the necessities and amenities of life. The relationship of the two parts of the society cannot exist in unidirectional, but the superstructure often affects the base though the base preemptily influence the society. That's why the poet says that though rich live in pomp and luxury and try to preserve the burned body's ashes in costly urns, cannot find the tranquility and happiness in their lives as the noble and virtuous rustic folks get in the country atmosphere. The rich are become madden in search of wealth and fame in the bottle-necked competition of the city life but all handful dusty works and labored hard go awry in the long struggling run. 


\section{Works Cited}

Cazamian, Louis. History of English. Macmillan, 1998

Mukherjee, S.K. : Selected Poems of Wordsworth. Ramabrothers, New Delhi, 2008.

Johari, J.M. Elegy Written in a Country Churchyard. Students Store, Bareilly, 1999.

Paul, Rajinder. Shakespeare's Sonnets. Ramabrothers, New Delhi, 1998.

Marx, Karl. A Contribution to the Critique of Political Economy. En.m.wikipedia.org>wiki> Base and superstructure 